Peter Kapalo ${ }^{1}$, Khrystyna Kozak ${ }^{2}$, Khrystyna Myroniuk ${ }^{2}$

\title{
THE ANALYSIS OF WATER SPEED INFLUENCE IN HOT-WATER DISTRIBUTION SYSTEM ON THE AMOUNT OF HEAT LOSS
}

\author{
${ }^{1}$ Institute of Architectural Engineering, \\ Faculty of Civil Engineering, Technical University of Kosice, Slovakia, \\ Lviv Polytechnic National University, Ukraine \\ ${ }^{2}$ Department of Gas Supply and Ventilation, \\ cr_i@ $@ u k r . n e t$
}

(C) Kapalo P., Kozak K., Myroniuk K., 2021

One of the main tasks around the world is to reduce energy consumption with constant consumer comfort. The hot water supply system uses a significant part of thermal energy and requires no less attention than the heating or ventilation system. The amount of heat loss from hot water distribution systems is of great importance for the energy consumption of buildings. In winter, part of this heat is used for space heating, in summer they are unused and is considered as lost heat.

For this reason, this paper considers the influence of water velocity in the pipe, pipe size and water temperature on the total heat losses in the insulated hot-water distribution system.

The data are presented in tabular and graphical form. A graph of the dependence of the amount of heat loss on the temperature and velocity of hot water is obtained.

Key words: hot water supply, distribution system, heat loss, heat transfer.

\section{Introduction}

Due to the constant rise in energy prices, it is simply necessary to find solutions to reduce the consumption of thermal energy in general and energy for hot water in particular. The energy consumption of the system consists of energy consumption for hot water preparation and losses in the system of distribution and production of thermal energy. In winter, the heat lost from the pipelines of the hot water supply system is partially spent on space heating. However, heat from hot water transferred through the walls of pipes to apartment buildings is an unused loss of heat energy in the summer season. (Kapalo, 2014). Due to the optimal insulation thickness of the pipes used in the distribution system, it is possible to significantly reduce heat loss from the hot water supply system to the environment (Sieniutycz, 2009; Keçebaş, 2011; Öztürk, 2006). Another optimization method is to minimize overhead, which includes investment in pipes and insulation and operating costs to pay for heat (Öztürk, 2006; Wepfer, 1979). In research works (Seddegh, 2015; Gorzin, 2018), was studied the heat transfer mechanism with combination of convection and conduction.

The underlying formula used to calculate heat transfer of insulated and uninsulated pipes are mentioned in the following references (Bejan, 2003; Kapalo, 2013 This paper did not cover the entire calculation algorithm, but only key concepts. The paper presents the results of research related to the assessment of the influence of hot water velocity on heat loss in distribution systems (STN EN 15316-3-3, 2007; Act No. 321/2014, 2014).

\section{The purpose of the article}

The aim of the article is to study the influence of hot water flow in the pipeline on the total thermal resistance during heat transfer from hot water to the environment near the distribution network. 


\section{Analysis of heat transfer processes in hot-water distribution systems}

The hot water distribution system consists mainly of heat-insulated pipes leading to mines and technical corridors. The proximity of the pipeline also significantly affects heat transfer. The magnitude of the heat flux from the pipe to the environment is described by following formula (1).

$$
\Phi=\frac{1}{\mathrm{R}} \cdot \mathrm{L} \cdot \Delta \mathrm{T}=\mathrm{U} \cdot \mathrm{L} \cdot \Delta \mathrm{T}
$$

where: $\Phi$ is the heat flow through the cylindrical wall, W; $\mathrm{U}$ is the heat transfer coefficient, $\mathrm{W} /\left(\mathrm{m}^{2} \cdot \mathrm{K}\right)$; $\Delta \mathrm{T}$ is the temperature difference, $\mathrm{K} ; \mathrm{L}$ is the length of the cylindrical wall section, $\mathrm{m} ; \mathrm{R}$ is the thermal resistance of the multilayer cylindrical wall, $\left(\mathrm{m}^{2} \cdot \mathrm{K}\right) / \mathrm{W}$.

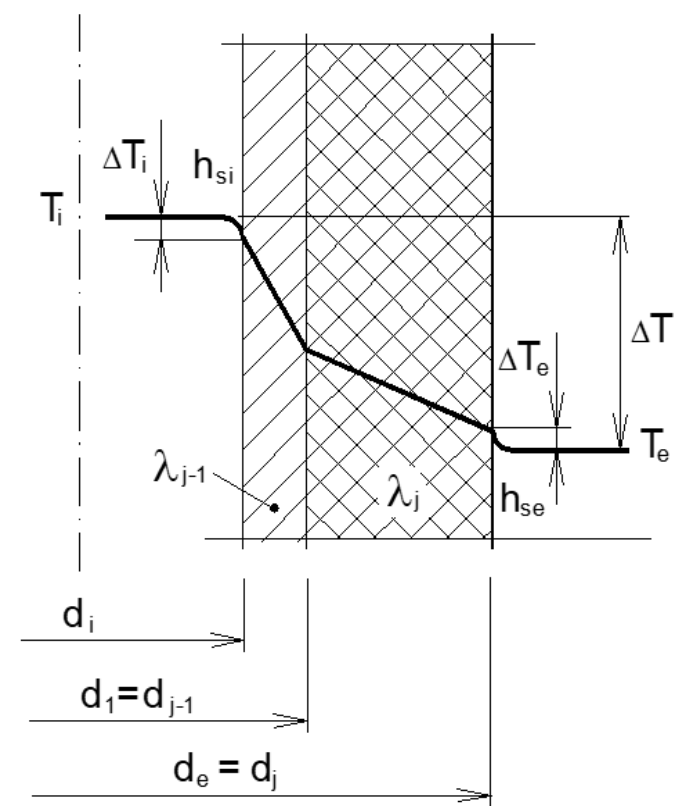

Fig. 1. Heat transfer through insulated circular pipes

The heat transfer coefficient $\mathrm{U}\left[\mathrm{W} /\left(\mathrm{m}^{2} \cdot \mathrm{K}\right)\right]$ of the cylindrical multilayer cylindrical wall (see Fig. 1) calculated by Formula (2):

$$
\mathrm{U}=\frac{\pi}{\frac{1}{\mathrm{~h}_{\mathrm{si}} \cdot \mathrm{d}_{\mathrm{i}}}+\sum_{\mathrm{j}=1}^{\mathrm{n}} \frac{1}{2 \cdot \lambda_{\mathrm{j}}} \cdot \ln \frac{\mathrm{d}_{\mathrm{j}}}{\mathrm{d}_{\mathrm{j}-1}}+\frac{1}{\mathrm{~h}_{\mathrm{se}} \cdot \mathrm{d}_{\mathrm{e}}}}
$$

where: $d_{e}$ is the outer diameter of the multilayer cylindrical wall, $m$; $d_{i}$ is the inner diameter of the multilayer cylindrical wall, $\mathrm{m} ; \mathrm{h}_{\mathrm{se}}$ is the heat transfer coefficient on the outer surface, $\mathrm{W} /\left(\mathrm{m}^{2} \cdot \mathrm{K}\right) ; \mathrm{h}_{\mathrm{si}}$ is the heat transfer coefficient on the inner surface, $\mathrm{W} /\left(\mathrm{m}^{2} \cdot \mathrm{K}\right) ; \mathrm{n}$ is the number of layers; $\mathrm{d}_{\mathrm{j}}$ is the outer diameter of the layer (insulation), $\mathrm{m} ; \mathrm{d}_{\mathrm{j}-1}$ is the inner diameter of the layer (insulation), $\mathrm{m} ; \lambda_{\mathrm{j}}$ is the coefficient of thermal conductivity of the layer, $\mathrm{W} /(\mathrm{m} \cdot \mathrm{K})$.

Equation (3) describes the total thermal resistance $\mathrm{R}\left[\left(\mathrm{m}^{2} \cdot \mathrm{K}\right) / \mathrm{W}\right]$ of a multilayer cylindrical wall per 1 meter of length - in our case, a water pipe insulated (Maguire et al, 2012):

$$
\mathrm{R}=\mathrm{R}_{\mathrm{si}}+\mathrm{R}_{\mathrm{r}}+\mathrm{R}_{\mathrm{iz}}+\mathrm{R}_{\mathrm{se}}
$$

where: $R_{\text {si }}$ is the thermal resistance of heat transfer by the flow from hot water to the inner surface of the pipe, $\left(\mathrm{m}^{2} \cdot \mathrm{K}\right) / \mathrm{W} ; \mathrm{R}_{\mathrm{r}}$ is the thermal resistance for heat transfer through the pipe wall, $\left(\mathrm{m}^{2} \cdot \mathrm{K}\right) / \mathrm{W} ; \mathrm{R}_{\mathrm{iz}}$ is the thermal resistance for the heat transfer through the thermal insulation, $\left(\mathrm{m}^{2} \cdot \mathrm{K}\right) / \mathrm{W} ; \mathrm{R}_{\mathrm{se}}$ is the thermal resistance of heat transfer by flow from the surface of the thermal insulation to the surroundings of the pipes, $\left(\mathrm{m}^{2} \cdot \mathrm{K}\right) / \mathrm{W}$. The aim of the article is to study the rate of influence of hot water on the inner part of 
the pipe, which affects the thermal resistance during heat transfer Rsi. The thermal resistance Rsi in the case of transfer can be formulated by the formula:

$$
\mathrm{R}_{\mathrm{si}}=1 /\left(\pi \cdot \mathrm{h}_{\mathrm{is}} \cdot \mathrm{d}_{\mathrm{i}}\right)
$$

where: $R_{\mathrm{si}}$ is the thermal resistance of heat transfer by the flow from hot water to the inner surface of the pipe, $\left(\mathrm{m}^{2} \cdot \mathrm{K}\right) / \mathrm{W} ; \mathrm{h}_{\mathrm{si}}$ is the heat transfer coefficient on the inner surface, $\mathrm{W} /\left(\mathrm{m}^{2} . \mathrm{K}\right) ; \mathrm{d}_{\mathrm{i}}$ is the inner diameter of the multilayer cylindrical wall, $\mathrm{m}$.

When hot water flows in the pipe, near the surface of the pipe, a hydrodynamic boundary layer of liquid is formed, in which the flow rate varies from $0 \mathrm{~m} / \mathrm{s}$ to the free flow rate. In convective heat transfer, heat transfer dominates near the surface of the tube, where the speed is very low, and the speed on the surface of the tube drops to zero. Heat transfer occurs in such a way that the liquid enters from the free flow into the boundary layer, where it transfers heat. Heat transfer occurs in such way that the liquid separates from the free flow to the boundary layer, where it transfers heat. When heat is transferred from a pipe to hot water, or vice versa, from hot water to a pipe, it is easy to assume a uniform temperature distribution in hot water, although the reality is more complicated. According to this assumption, it is possible to describe the heat transfer according to Fig. 2.

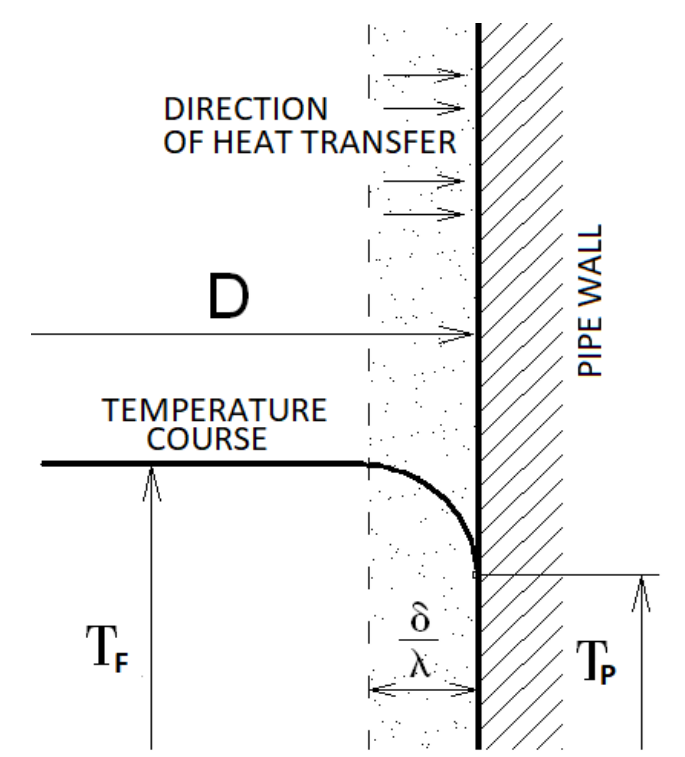

Fig. 2. The thermal insulating effect

of the boundary layer of the fluid during heat transfer

To describe heat transfer, the ratio for heat flux $\Phi(\mathrm{W})$ is used:

$$
\Phi=\mathrm{h}_{\mathrm{si}} \cdot \mathrm{A} \cdot\left(\mathrm{T}_{\mathrm{f}}-\mathrm{T}_{\mathrm{s}}\right)
$$

where: $T_{f}$ is the mean temperature of liquid (hot water), $K$; $T_{s}$ is the pipe surface temperature, $K$; $A$ is the pipe surface area, $\mathrm{m}^{2} ; \mathrm{h}_{\mathrm{si}}$ is the heat transfer coefficient on the inner surface, $\mathrm{W} /\left(\mathrm{m}^{2} \cdot \mathrm{K}\right)$. The heat transfer coefficient $h_{s i}$ depends on the properties of the fluid, her state of movement, on the surface of the pipe (insulation). The heat transfer coefficient $h_{\mathrm{si}}$ is a complex function with a large number of variables that determine the entire heat transfer process.

The flow of hot water in the internal water supply at modes close to the calculated one has the character of turbulent flow. In turbulent flow, which most often occurs in the case of hot water distribution, is an intensive mixing of the fluid particles. According to (Schack, 1965) in the case of turbulent flow, the formula (6) can express the heat transfer coefficient:

$$
h_{s i}=3370 \cdot\left(1+0.014 \cdot \theta_{f}\right) \cdot v^{0,85},
$$

where: $\Theta_{\mathrm{f}}$ is the mean temperature of hot water, ${ }^{\circ} \mathrm{C}$; $\mathrm{v}$ is the flow velocity, $\mathrm{m} / \mathrm{s}$.

The results of the calculated heat transfer coefficients are documented in Fig. 3. 


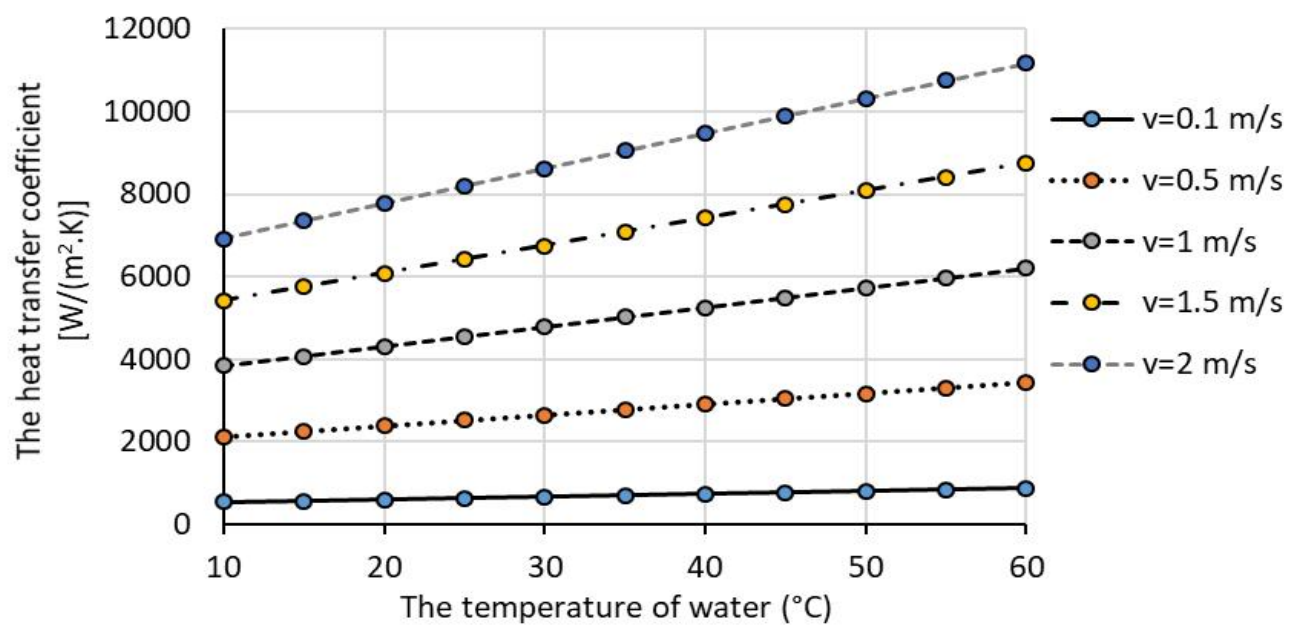

Fig. 3. The calculated heat transfer coefficients

Fig. 3 shows the heat transfer coefficients for certain diameters of pipes, which are most often used in the distribution of hot water in rooms in apartment buildings. During the circulation of hot water in the distribution system to maintain a constant water temperature in the system, the water temperature is maintained at $50{ }^{\circ} \mathrm{C}$, even when hot water is not consumed. Therefore, the water flow is a constant value that depends on the diameter of the pipe.

Table 1

The linear heat flow

\begin{tabular}{|c|c|c|c|}
\hline $\begin{array}{c}\text { The nominal steel pipe } \\
\text { size } \\
\mathrm{D}_{\mathrm{N}} \\
{[\mathrm{mm}]}\end{array}$ & $\begin{array}{l}\text { The linear heat flow with } \\
\qquad \mathrm{R}_{\mathrm{si}} \\
\Phi_{1} \\
{[\mathrm{~W} / \mathrm{m}]}\end{array}$ & $\begin{array}{c}\text { The linear heat flow } \\
\text { without } \mathrm{R}_{\mathrm{si}} \\
\Phi_{2} \\
{[\mathrm{~W} / \mathrm{m}]}\end{array}$ & $\begin{array}{l}\text { The difference between linear } \\
\text { heat flows } \\
\Phi_{1}-\Phi_{2} \\
{[\mathrm{~W} / \mathrm{m}]}\end{array}$ \\
\hline 15 & 7.571 & 7.586 & 0.0143 \\
\hline 20 & 8.895 & 8.918 & 0.0227 \\
\hline 25 & 10.510 & 10.547 & 0.0362 \\
\hline 32 & 12.544 & 12.613 & 0.0694 \\
\hline
\end{tabular}

The effect of the rate of hot water in the pipes on the total heat loss of the distribution system in percent is shown in Fig. 4.

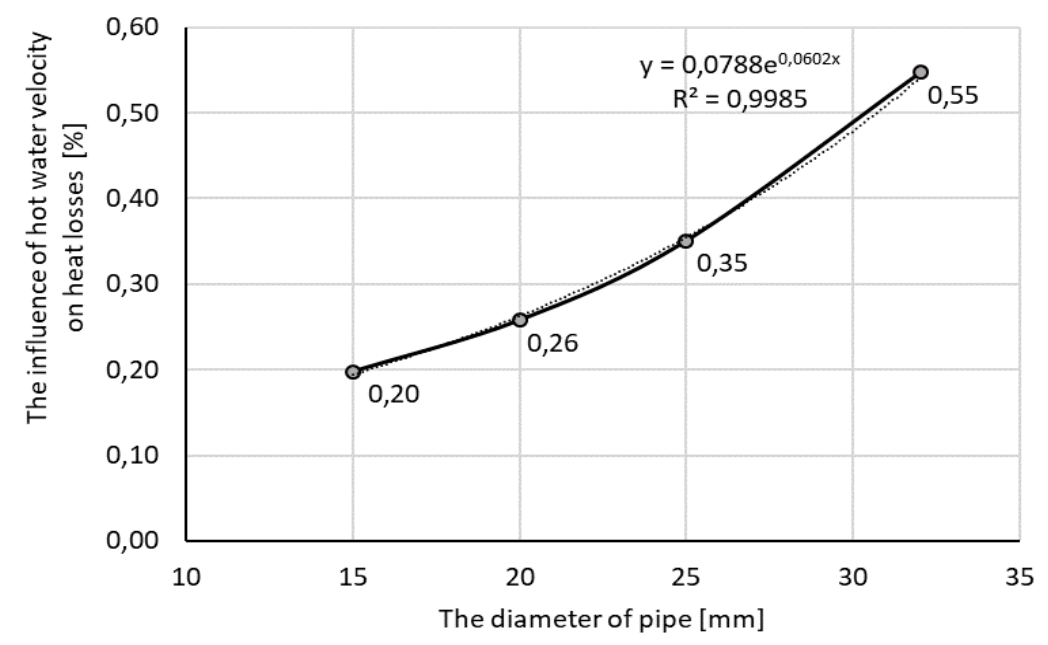

Fig. 4. The influence of hot water velocity in pipes on the total heat loss 
In the research were analyzed the steel pipes $D_{N} 15,20,25$ and $32 \mathrm{~mm}$ with thermal insulation of thick $20 \mathrm{~mm}$, with the thermal conductivity coefficient $\lambda=0.04 \mathrm{~W} /(\mathrm{m} \cdot \mathrm{K})$. Table 1 presents the results of the linear heat flux, which are calculated for two alternative variants. In the first case, a linear heat flux $\Phi_{1}$ with thermal resistance $R_{s i}$, which is affected by the hot water flow rate, was calculated. In the second alternative, a linear heat flux $\Phi_{2}$ without thermal resistance $R_{\text {si }}$ was calculated.

\section{Conclusions}

From the analysis of the influence of hot water velocity in the hot water distribution system it can be stated:

1. The velocity of hot water in the pipes in the normal operating mode, i.e. for the velocity of water from 0.1 to $0.5 \mathrm{~m} / \mathrm{s}$, has an effect of $0.2 \%$ to $0.55 \%$ for the total heat flow through the wall of the pipe.

2. When designing the thermal insulation of hot water distribution in apartment buildings, where the steel pipe sizes are $D_{N} 15, D_{N} 20, D_{N} 25$ and $D_{N} 32 \mathrm{~mm}$, can be to ignore.

Acknowledgments: This article was elaborated in the framework of the project VEGA 1/0697/17.

\section{References}

Kapalo, P. \& Lukáč, P. (2014). The hot water distribution systems analysis from heat losses point of view. 14th International Multidisciplinary Scientific Geoconference and EXPO, SGEM 2014; Albena; Bulgaria; Vol. 1(4), pp. 545-552.

Sieniutycz, S., Jeżowski, J. (2009). Energy Optimization in Process Systems. eBook ISBN: 9780080914428, Elsevier, Oxford, UK.

Keçebaş, A., Alkan, M. A., Bayhan, M. (2011). Thermo-economic analysis of pipe insulation for district heating piping systems, Applied Thermal Engineering, Vol. 31(17-18), pp. 3929-3937, ISSN 1359-4311, https://doi.org/10.1016/j.applthermaleng.2011.07.042.

Öztürk, İ. T. \& Karabay, H. \& Bilgen, E. (2006). Thermo-economic optimization of hot water piping systems: A comparison study, Energy, Elsevier, vol. 31(12), pp. 2094-2107. DOI: 10.1016/j.energy.2005.10.008.

Bejan, A., Kraus, A. D. (2003) Heat Transfer Handbook. John Wiley \& Sons, ISBN 0-471-39015-1.

Kapalo, P., Böszörmenyi, L. (2013). Energy analysis of hot water distribution system - interrupted operation. 2nd International Conference on Industrial Design and Mechanics Power, ICIDMP 2013; Nanjing; China; 24 August 2013 through 25 August 2013; Applied Mechanics and MaterialsVolume 437, 2013, Pages 1062-1065; Code 100448.

Schack, A. (1965). Industrial heat transfer. London: Chapman and Hall. 1965

Wepfer, W. J., Gaggioli, R. A., and Obert, E. F. (1979). Economic Sizing of Steam Piping and Insulation. ASME. J. Eng. Ind. November 1979; 101(4): 427-433. https://doi.org/10.1115/1.3439532

Seddegh, S., Wang, X., Henderson, A. D. (2015). Numerical investigation of heat transfer mechanism in a vertical shell and tube latent heat energy storage system. Applied Thermal Engineering, Volume 87, 2015, Pages 698-706, ISSN 1359-4311, https://doi.org/10.1016/j.applthermaleng.2015.05.067.

Gorzin, M., Hosseini, M. J. Ranjbar A. A., Bahrampoury, R. (2018). Investigation of PCM charging for the energy saving of domestic hot water system. Applied Thermal Engineering, Volume 137, 2018, Pages 659-668, ISSN 1359-4311, https://doi.org/10.1016/j.applthermaleng.2018.04.016.

Maguire J., Fang X., Krarti M. (2012). An Analysis Model for Domestic Hot Water Distribution Systems. ASME 2011, 5-th International Conference on Energy Sustainability, August 7-10, 2011, Washington, DC, USA, Pages 1937-1946. https://doi.org/10.1115/ES2011-54145.

CEN (2007). STN EN 15316-3-3. Heating systems in buildings - Method for calculation of system energy requirements and system efficiencies - Part 3-3: Domestic hot water systems, generation.

Act No. 321/2014. (2014). Coll. on Energy Efficiency and amendments of certain acts as amended. (in Slovak). 
П. Капало, Х. Р. Козак ${ }^{2}$, Х. В. Миронюк ${ }^{2}$

${ }^{1}$ Технічний університет Кошице, Інститут архітектурного будівництва, Кошице, Словаччина

${ }^{2}$ Національний університет "Львівська політехніка", кафедра теплогазопостачання та вентиляції

\section{АНАЛІЗ ВПЛИВУ ШВИДКОСТІ ВОДИ В СИСТЕМІ ГАРЯЧОГО ВОДОПОСТАЧАННЯ НА ВЕЛИЧИНУ ВТРАТ ТЕПЛОТИ}

( Капало П., Козак Х. Р., Миронюк Х. В., 2021

Побутовий сектор та промисловість в Україні сьогодні надзвичайно енерговитратні, а це означає, що потрібно докласти максимальних зусиль для зменшення витрат енергії, не погіршуючи якості послуг.

Система гарячого водопостачання використовує значну частину теплової енергії та потребує не меншої уваги, ніж система опалення або вентиляції. Величина втрат теплоти в підсистемі розподілення гарячої води має велике значення для енергоспоживання будівель. Взимку частина цієї теплоти використовується для опалення приміщень, влітку ця енергія не використовується з користю та вважається втраченою.

У роботі розглянуто вплив швидкості води в трубі на загальні втрати теплоти в теплоізольованій підсистемі розподілення гарячої води. Для цього проаналізовано процес передавання тепла від води до стінки труби та від стінки до навколишнього середовища.

У роботі детально розглянуто на теплопередачу від води до стінки труби, а також витрату води в трубі та їі частку в загальних втратах теплоти підсистемою розподілення гарячої води.

Дані подано у табличній та графічній формах. Отримано графік залежності величини тепловтрат від температури та швидкості руху гарячої води. Температура води змінювалася від 10 до $60{ }^{\circ} \mathrm{C}$, а швидкість води від 0,1 до 2,0 м/с, що дало змогу проаналізувати величину тепловтрат при різних вихідних даних.

Крім того, визначено величину теплового потоку через стінку труби за різних діаметрів ізольованої сталевої труби. Діаметр трубопроводу змінювався від 15 до 32 мм. В результаті досліджень одержано дані, згідно з якими можна стверджувати, що теплопередача від води до стінки труби незначна і цією величиною можна знехтувати.

Ключові слова: гаряче водопостачання, підсистема розподілення, тепловтрати, теплопередача. 